\title{
Inhibition of livin expression suppresses cell proliferation and enhances chemosensitivity to cisplatin in human lung adenocarcinoma cells
}

\author{
LI ZHUANG $^{1}$, LI-DA SHEN ${ }^{1}$, KUN LI $^{1}$, RUN-XIANG YANG ${ }^{1}$, QIN-YONG ZHANG ${ }^{1}$, YUN CHEN ${ }^{1}$, \\ CHUN-LIN GAO ${ }^{1}$, CHAO DONG $^{1}$, QING BI $^{1}$, JING-NAN TAO ${ }^{1}$, XIAO-NAN WANG ${ }^{1}$ and QING TIAN ${ }^{2}$ \\ ${ }^{1}$ Department of Medical Oncology, Yunnan Cancer Hospital, Kunming Medical University, Kunming, Yunnan 650118; \\ ${ }^{2}$ Department of Cardiology, The First People's Hospital of Kunming, Yunnan 650011, P.R. China
}

Received March 21, 2014; Accepted December 3, 2014

DOI: $10.3892 / \mathrm{mmr} .2015 .3372$

\begin{abstract}
Livin is a novel member of the inhibitor of apoptosis protein family that has been reported to be overexpressed in various types of human malignancy. Although several studies have demonstrated that livin may be used as an effective target for tumor therapy, few studies have investigated its role in human lung adenocarcinoma. In the present study, two different methods were used in order to investigate the tumor-suppressing effect of livin in human lung adenocarcinoma cells. Firstly, small interfering (si)RNA technology was used to down regulate livin expression; siRNA-mediated knockdown of livin was confirmed using reverse transcription quantitative polymerase chain reaction and western blot analysis, and cell proliferations was assessed using an MTT assay in vitro. Secondly, inhibition of livin expression was induced through the synergistic inhibitory effect between flavopiridol and tumor necrosis factor-related apoptosis-inducing ligand (TRAIL). Experimental results revealed that, following transfection of the livin gene-silencing vector, the gene expression of livin was markedly decreased, SPC-A1 cell proliferation was significantly reduced and the therapeutic effect of the chemotherapy drug cisplatin was markedly improved. This growth inhibitory effect was also observed in the flavopiridol and TRAIL combination treatment group. In the flavopiridol and TRAIL combination treatment group, the protein expression of livin was significantly reduced and the survival rate of SPC-A1 cells was significantly lower than the flavopiridol and TRAIL single operation group. In conclusion, the RNA silencing and the synergistic inhibitory effect between
\end{abstract}

Correspondence to: Mrs. Li Zhuang, Department of Medical Oncology, Yunnan Cancer Hospital, Kunming Medical University, 519 Kunzhou Road, Kunming, Yunnan 650118, P.R. China E-mail: zhuanglikxy@126.com

Key words: livin, RNA interference, flavopiridol, tumor necrosis factor-related apoptosis-inducing ligand, cisplatin, SPC-A1 cells flavopiridol with TRAIL was able to effectively inhibit the expression of livin, significantly decrease SPC-A1 tumor cell proliferation and significantly enhance sensitivity to the chemotherapy drug cisplatin. These findings suggest that livin may be used as a novel target for tumor gene therapy.

\section{Introduction}

Lung cancer is the leading cause of cancer-associated mortality among males and the second leading cause among females worldwide (1). The incidence of lung cancer is increasing in females worldwide and is the main cause of cancer-associated mortality among females in Europe and the USA, exceeding breast and cervical cancer (2-10). Lung adenocarcinoma is currently the most common pathological type of lung cancer $(11,12)$ and is the primary type of lung cancer in females, adolescents and non-smokers.

Livin, a novel member of the inhibitor of apoptosis (IAP) protein family, is not detected in the majority of normal tissues, however, is highly expressed in various types of human malignancy (13-30). Increased activity of this protein may be used as a reliable prognostic factor for initial and late resistance to chemotherapeutic drugs in certain types of human tumor (31-37). Inhibition of livin gene expression may effectively promote tumor cell apoptosis and raise the sensitivity of tumor cells to different treatments in vitro $(35,36)$. Although several studies have demonstrated that livin may be used as an effective target for tumor therapy (38-40), few studies have focused on human lung adenocarcinoma. Therefore, the present study aimed to investigate the treatment effect of livin expression inhibition in lung adenocarcinoma.

In the present study, two different methods were used to investigate the tumor-suppressing effect of livin in human lung adenocarcinoma. Firstly, small interfering (si)RNA technology was used to downregulate livin expression, which was confirmed by reverse transcription quantitative polymerase chain reaction (RT-qPCR) and western blot analysis. In addition, cell proliferation was assessed using an MTT assay in vitro. Secondly, inhibition of livin expression was induced through the synergistic inhibitory effect between flavopiridol and tumor necrosis factor-related apoptosis-inducing ligand 
(TRAIL). Furthermore, the effect of the inhibition of livin expression on SPC-A1 tumor cell proliferation and sensitivity to the chemotherapy drug cisplatin was investigated. The combination of chemotherapy and downregulation of livin expression may contribute to the treatment of human lung adenocarcinoma drug-resistant tumor cells.

\section{Materials and methods}

Materials. The human lung adenocarcinoma SPC-A1 cell line was acquired from Nanjing KeyGen Biotech., Co., Ltd. (Nanjing, China). The primers for livin siRNA and control siRNA were synthesized by Beijing Genomics Institute (Beijing, China). All antibodies were purchased from Santa Cruz Biotechnology, Inc. (Santa Cruz, CA, USA).

Drugs and reagents. Dulbecco's modified Eagle's medium (DMEM) and fetal bovine serum (FBS) were purchased from Gibco-BRL (Carlsbad, CA, USA). TRIzol reagent and Lipofectamine 2000 were obtained from Invitrogen Life Technologies (Carlsbad, CA, USA). Reverse Transcriptase SYBR Green Master mixture was acquired from Takara Bio, Inc. (Otsu, Japan). The bicinchoninic acid protein assay kit and ECL-Plus kit were purchased from Thermo Scientific (Rockford, IL, USA). The MTT cell proliferation assay kit was purchased from Sangon Biotech (Shanghai, China) and TRAIL was purchased from Merck Millipore (Darmstadt, Germany). In addition, flavopiridol was obtained from Sigma-Aldrich (St. Louis, MO, USA) and Z-VAD-FMK was purchased from R\&D Systems (Minneapolis, MN, USA).

Cell culture and transfection. SPC-A1 cells were cultured in DMEM medium supplemented with $10 \%$ heat-inactivated FBS. All were placed in a humidified incubator, containing 5\% $\mathrm{CO}_{2}$ at $37^{\circ} \mathrm{C}$. SPC-A 1 cells were replated at $2 \times 10^{5}$ cells/well in six-well plates once they had reached exponential phase. When the cell density reached $40-50 \%$, cells were transfected with Lipofectamine 2000 with a pcDNA3.1 expression vector (Invitrogen Life Technologies) and cultured at $37^{\circ} \mathrm{C}$ and $5 \% \mathrm{CO}_{2}$ for $24 \mathrm{~h}$. The clone in which the livin-siRNA was transfected was termed the livin-siRNA group, the group transfected with the negative control vector was termed the negative control (NC) group and SPC-A1 cells were termed the control (CON) group. The following RNA silencing sequences were used: siRNA-livin790, forward 5'-GAGAGGUCCAGUCUGAAAG-3' and reverse 5'-CUUUCAGACUGGACCUCUC-3' and siRNA-livin180, forward 5'-CCUAAAGACAGUGCCAAGU-3' and reverse 5'-ACUUGGCACUGUCUUUAGG-3'.

$R T$-qPCR. Total RNA was isolated with TRIzol reagent and reverse-transcribed to synthesize cDNA. cDNA was subsequently amplified by SYBR-Green based qPCR using the following primers: Livin, forward 5' - GGAGAGAGGTCCAGTCTGAAAGT-3' and reverse 5'-ACCTTGCACGTCCTCTCCTC-3' and Homosapiens histone acetyltransferase (HBOA), forward 5'-ATCAAAGAAATCAGTCAGGAGACG-3' and reverse 5'-CTCTTTGGCTATCCACTCATCAAT-3'. The $25 \mu$ l fluorescent PCR reaction mix contained: $8.5 \mu 1 \mathrm{ddH}_{2} \mathrm{O}, 12.5 \mu \mathrm{l} 2 \mathrm{X}$
SYBR Premix Ex Taq II, $2 \mu \mathrm{l}$ cDNA and $1.0 \mu \mathrm{l}$ forward and reverse primers $(10 \mu \mathrm{mol} / \mathrm{l})$, respectively. The cycling parameters were as follows: 40 cycles, including denaturation at $95^{\circ} \mathrm{C}$ for $5 \mathrm{sec}$, annealing at $60^{\circ} \mathrm{C}$ for $30 \mathrm{sec}$ and extension at $72^{\circ} \mathrm{C}$ for $30 \mathrm{sec}$. Melting curve analysis was used to confirm the primer specificity. The comparative cycle threshold $(\mathrm{Ct})$ method was used for calculation of livin mRNA expression. The calculation methods were as follows: $\Delta \mathrm{Ct}=\mathrm{Ct}$ (Livin) - $\mathrm{Ct}$ (HBOA), $\Delta \Delta \mathrm{Ct}=\Delta \mathrm{Ct}$ (Treatment) $-\Delta \mathrm{Ct}$ (Control). $\Delta \Delta \mathrm{Ct}$ mean values were compared between groups. The relative mRNA expression was expressed in $2^{-\Delta \Delta \mathrm{Ct}}$.

Western blot analysis. SPC-A1 cells were harvested after $48 \mathrm{~h}$ of transfection and extracted using lysis buffer. Cell extracts were separated on $15 \%$ sodium dodecyl sulfate polyacrylamide gel electrophoresis. Separated protein bands were electrotransferred onto polyvinylidene fluoride (PVDF) membranes (Millipore, Bedford, MA, USA). Finally, $5 \%$ skimmed milk powder was used to block the PVDF membranes for $1 \mathrm{~h}$. The membrane was incubated overnight at $4^{\circ} \mathrm{C}$ with a 1:100 dilution of mouse monoclonal anti-livin primary antibody (sc-166390; Santa Cruz Biotechnology, Inc.). The following day, goat anti-mouse Immunoglobulin $\mathrm{G}$ horesradish peroxidase-conjugated secondary antibodies (sc-2005; Santa Cruz Biotechnology, Inc.) were added at a dilution of $1: 2,000$ and the mixture was incubated for $2 \mathrm{~h}$ at room temperature. PVDF membranes were washed in phosphate-buffered saline four times. The ECL-Plus kit was used to visualize the immunoreactive bands. Relative protein level was normalized by $\beta$-actin concentration. Three separate experiments were performed in duplicate for each treatment.

Cell proliferation assay. Cell viability was assessed using an MTT assay. Cells were cultured in 24 well plates at a concentration of $5 \times 10^{4}$ cells per well and allowed to adhere. SPC-A1 cells were termed the CON group. The group transfected with the negative control vector was termed the NC group. The group transfected with the livin-siRNA vector was termed the livin-siRNA group. The group initially transfected with livin-siRNA and then treated with $1.2 \mu \mathrm{g} / \mathrm{ml}$ cisplatin was termed the livin-siRNA+cisplatin group. The FP group was treated with $100 \mathrm{nmol} / \mathrm{l}$ flavopiridol and the $\mathrm{T}$ group was treated with $100 \mathrm{ng} / \mathrm{ml}$ TRAIL. The cisplatin treatment group was treated with $1.2 \mu \mathrm{g} / \mathrm{ml}$ cisplatin. The $\mathrm{F}+\mathrm{T}$ treatment group was treated with $100 \mathrm{nmol} / \mathrm{l}$ flavopiridol and $100 \mathrm{ng} / \mathrm{ml}$ TRAIL. The FP+T+cisplatin treatment group was treated with $100 \mathrm{nmol} / \mathrm{l} \mathrm{FP}, 100 \mathrm{ng} / \mathrm{ml}$ TRAIL and $1.2 \mu \mathrm{g} / \mathrm{ml}$ cisplatin. The $\mathrm{Z}$-VAD-FMK group was treated with flavopiridol, $50 \mu \mathrm{mol} / 1$ Z-VAD-FMK and TRAIL. Following treatment for $24 \mathrm{~h}, 100 \mu \mathrm{l}$ MTT $(0.5 \mathrm{mg} / \mathrm{ml})$ was added to the cells and the mixture was incubated for $4 \mathrm{~h}$ at $37^{\circ} \mathrm{C}$. Subsequently, the supernatant was removed, dimethyl sulfoxide was used to dissolve the resultant formazan crystals and the absorbance value was read at $570 \mathrm{~nm}$ using a Smartspec 3000 spectrophotometer (Bio-Rad Laboratories, Inc., Hercules, CA, USA).

Statistical analysis. SPSS 13.0 (SPSS, Inc., Chicago, IL, USA) was used for the data analysis. All experiments were repeated three times and data are presented as the mean \pm standard deviation. Differences between groups were analyzed using 


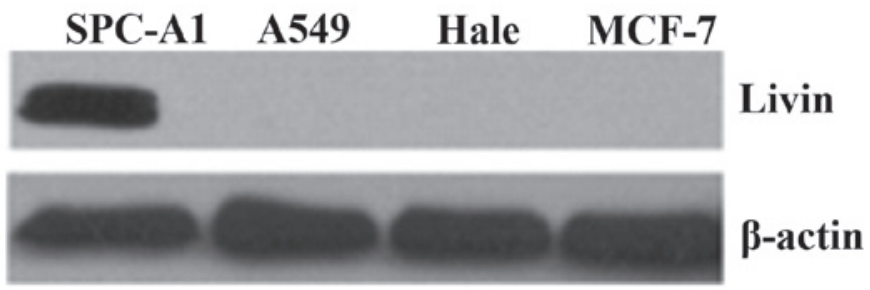

Figure 1. Protein expression of livin in human SPC-A1 cells. The protein expression of livin was investigated by western blot analysis in four cell lines (SPC-A1, A549, Hale and MCF-7). A relatively high protein expression of livin was observed in SPC-A1 cells.

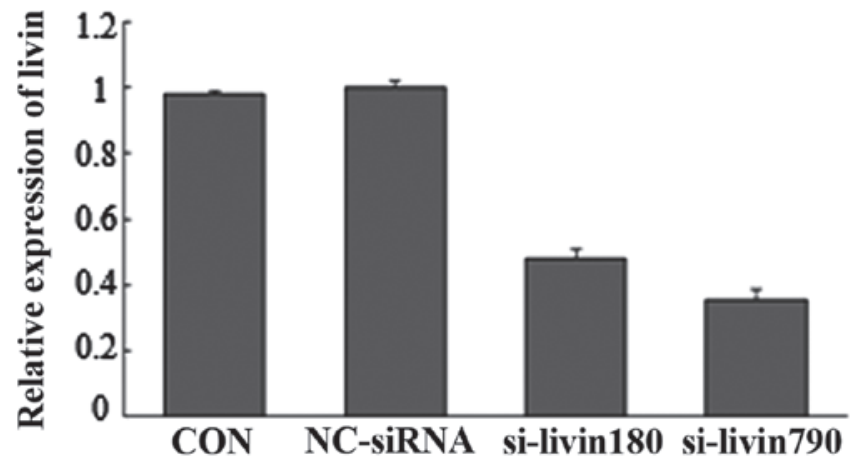

Figure 2. Silencing of livin gene expression by RNAi in SPC-A1 cells. The knockdown efficiency of two candidate siRNAs (si-livin180 and si-livin790) was evaluated using reverse transcription-quantitative polymerase chain reaction. The mRNA expression of livin in cells transfected with si-livin790 and si-livin 180 were significantly decreased to 52 and $64.4 \%$, respectively. NC, negative control; CON, control.

one-way analysis of variance. $\mathrm{P}<0.05$ was considered to indicate a statistically significant difference.

\section{Results}

Protein expression of livin in the human SPC-A1 cell line. The protein expression of livin was investigated using western blot analysis in several cell lines (SPC-A1, A549, Hale and MCF-7). As shown in Fig. 1, livin protein expression was only observed in SPC-A1 cells.

Silencing of livin gene expression by RNAi in SPC-AI cells. The knockdown efficiency of two candidate siRNA (siRNA-livin180 and siRNA-livin790) was evaluated using RT-qPCR. The results revealed that the livin mRNA level in cells transfected with siRNA-livin790 and siRNA-livin180 were significantly decreased to 52 and $64.4 \%$, respectively (Fig. 2). The most significant silencing effect was observed with siRNA-livin790, therefore, the siRNA-livin790 transfection group was used in the follow-up experiment.

Synergy between flavopiridol and TRAIL affects livin expression. The synergistic inhibitory effect between flavopiridol and TRAIL on livin protein expression was evaluated by western blot analysis. Compared with either flavopiridol or TRAIL alone, combining flavopiridol with TRAIL significantly decreased the protein expression level of livin (Fig. 3). No significant difference was identified between flavopiridol and TRAIL treatment groups.

Effects of inhibitor Z-VAD-FMK on livin protein expression. The result of western blot analysis demonstrated that the

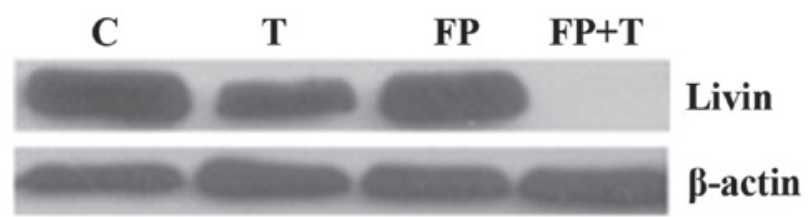

Figure 3. Synergistic inhibitory effect between flavopiridol and TRAIL on the protein expression of livin. The synergistic inhibitory effects between flavopiridol and TRAIL on livin protein expression were evaluated by western blot analysis. Compared with either flavopiridol or TRAIL alone, combining flavopiridol with TRAIL significantly decreased the protein expression level of livin. No significant difference was identified between flavopiridol and TRAIL treatment groups. C, control group; FP, flavopiridol treatment group; T, TRAIL treatment group; FP+T, flavopiridol with TRAIL treatment group; TRAIL, tumor necrosis factor-related apoptosis-inducing ligand.

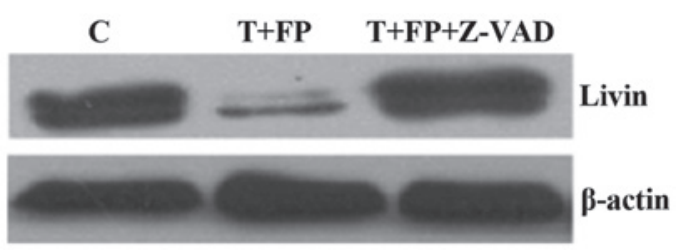

Figure 4. Effect of the caspase inhibitor Z-VAD-FMK on livin protein expression. The effects of caspase inhibitor Z-VAD-FMK on livin protein expression were evaluated by western blot analysis. The synergistic inhibitory effects between flavopiridol and TRAIL were able to effectively inhibit the protein expression of livin, while the caspase inhibitor Z-VAD-FMK reversed this inhibitory effect. C, control group; T+FP, flavopiridol with TRAIL treatment group; TRAIL, tumor necrosis factor-related apoptosis-inducing ligand.

synergistic inhibitory effect between flavopiridol and TRAIL may effectively inhibit the protein expression of livin, while the caspase inhibitor Z-VAD-FMK reversed this inhibitory 


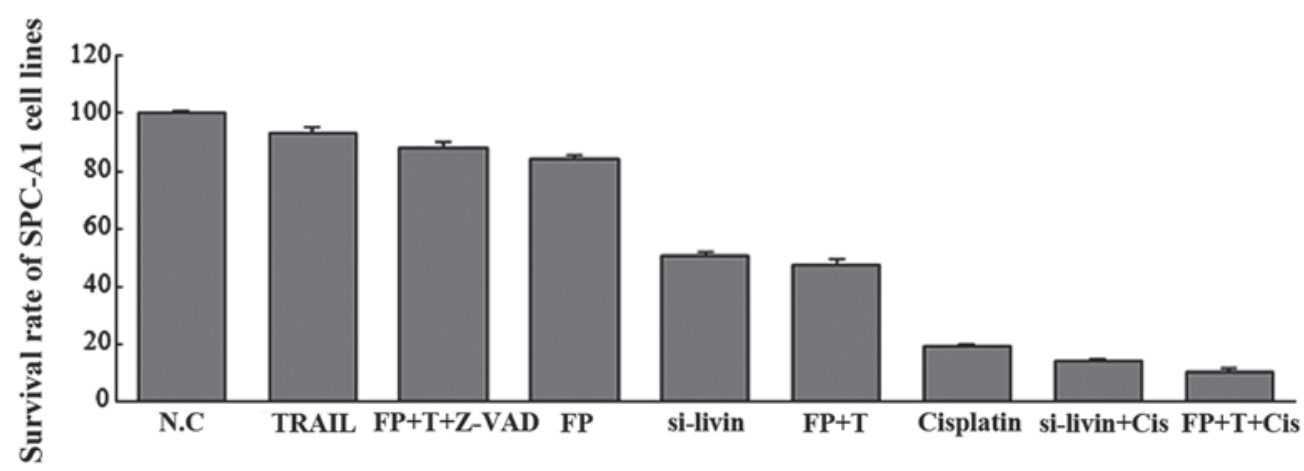

Figure 5. Effect of livin inhibition on cell proliferation. An MTT assay was used to investigate the proliferative activities of SPC-A1 cells. Data was normalized to the control group. Suppression of livin resulted in a significant decrease in the proliferation rate of SPC-A1 cells and enhanced sensitivity to the chemotherapy drug cisplatin. FP, flavopiridol treatment group; T, TRAIL treatment group; FP+T, flavopiridol with TRAIL treatment group; TRAIL, tumor necrosis factor-related apoptosis-inducing ligand.

effect. As shown in Fig. 4, expression of livin protein in the $\mathrm{T}+\mathrm{FP}+\mathrm{Z}-\mathrm{VAD}$ treatment group was significantly higher than the T+FP group and no significant difference was identified between the control group and T+FP+Z-VAD treatment group.

Effect of livin inhibition on cell proliferation. To elucidate the effect of livin inhibition on tumor growth in SPC-A1 cells, an MTT assay was used to evaluate the tumor cell proliferative activities. The survival rate of each group was as follows: Flavopiridol group, $84.30 \pm 1.34 \%$; TRAIL group, $93.40 \pm 1.56 \%$; $\mathrm{F}+\mathrm{T}$ combination group, $48.02 \pm 1.35 \%$; siRNA-livin group, $50.88 \pm 1.14 \%$; cisplatin group, $19.30 \pm 0.89 \%$; siRNA-livin+cisplatin group, $14.37 \pm 0.81 \%$; FP+T+cisplatin group, $10.86 \pm 0.87 \%$ and the Z-VAD-FMK group, $88.16 \pm 1.64 \%$. The data were normalized to the control group (Fig. 5). As illustrated in Fig. 5, suppression of livin resulted in a significant decrease in the proliferation rate of SPC-A1 cells at $48 \mathrm{~h}$ and this suppression effect unexpectedly enhanced the sensitivity of cells to the chemotherapy drug cisplatin.

\section{Discussion}

The anti-apoptotic effect of the IAP family is possibly regulated through inhibition of the caspase signaling cascade, inhibiting the cell death receptor tumor necrosis factor receptor-mediated apoptosis signaling pathway and interaction with nuclear factor- $\kappa \mathrm{B}$. The IAP family has several family members, including $\mathrm{x}$-linked inhibitor of apoptosis protein, baculoviral IAP repeat-containing protein 1 and 3, cellular IAP1, Apollon (Bruce), IAP-like protein-1, Survivin and livin. The structure of IAP family members is highly conserved, containing $\mathrm{Cys} / \mathrm{His}$ baculovirus IAP repeats and a $\mathrm{COOH}$-terminal ring finger, which has E3 ubiquitin ligase activity and is critical in the regulation of proliferation and apoptosis (41).

Livin, a novel member of the IAP family, is important in apoptosis, cell proliferation and cell cycle control (20). It has been demonstrated to be expressed in transformed cells and multiple types of malignant tumor, including neuroblastoma (20) as well as carcinomas of the bladder $(21,22)$, lung (23), nasopharynx (24), kidney (25), liver (26), colon/rectum (27), skin (28), bone (29) and stomach (30).
Silencing livin leads to apoptosis induction, cell cycle arrest and proliferation inhibition in malignant tumor cells (42-50).

The present study investigated the clinical significance of livin in SPC-A1 cells and examined the potential of using RNA interference to knock down livin expression, including the subsequent effects on tumor growth in SPC-A1 cells in vitro. The present results demonstrated that, following transfection of the livin gene-silencing vector, the expression of the livin gene was significantly decreased, SPC-A1 cell proliferation was significantly reduced and the therapeutic effect of the chemotherapy drug cisplatin was markedly improved. The livin-mediated signaling pathway remains to be elucidated, although a number of studies have demonstrated that silencing livin promotes tumor cell apoptosis by regulating mitomycin, tumor necrosis factor- $\alpha$, caspase- 3 and caspase-9 (45) and mediates gastric tumor cell invasion via MAPK signaling (51). The livin-mediated signaling pathway requires further investigation.

TRAIL, as a member of the tumor necrosis factor gene superfamily, selectively induces apoptosis in numerous transformed cells, excluding normal cells. The synergistic inhibitory effect between TRAIL and chemotherapy drugs has been examined in ovarian carcinoma (52), the combination resulted in increased sensitivity to TRAIL, promoted induction of apoptosis, reduced drug dosage and decreased normal tissue toxicity. Through mediating cell cycle arrest and apoptosis in breast cancer cells, flavopiridol has made important contributions to increasing drug effectiveness and identifying new drug targets (53).

The synergistic inhibitory effect between flavopiridol and TRAIL has been demonstrated in SPC-A1 cells (54). The present study aims to further confirm this synergistic inhibitory effect on apoptosis promotion and examine whether this combination may enhance chemosensitivity. The current results revealed that the expression of livin protein was significantly reduced in the flavopiridol and TRAIL combination treatment group. The survival rate of SPC-A1 cells in the combination treatment group was significantly compared the groups treated with flavopiridol or TRAIL alone. Additionally, the survival rate was lowest in the group treated with a combination of flavopiridol, TRAIL and cisplatin.

In conclusion, the RNA silencing and the synergistic inhibitory effect between flavopiridol with TRAIL was able 
to effectively inhibit the expression of livin, significantly decrease SPC-A1 tumor cell proliferation and significantly enhance sensitivity to the chemotherapy drug cisplatin. These findings suggest that livin may be used as a novel target for tumor gene therapy.

\section{Acknowledgements}

This study was supported by a grant from the Natural Science Foundation of Yunnan Province (grant no. 2010ZC131).

\section{References}

1. Novaes FT, Cataneo DC, Ruiz RL Jr, et al: Lung cancer: histology, staging, treatment and survival. J Bras Pneumol 34 595-600, 2008 (In English and Portuguese).

2. Thomas L, Doyle LA and Edelman MJ: Lung cancer in women: emerging differences in epidemiology, biology, and therapy. Chest 128: 370-381, 2005.

3. Novello $\mathrm{S}$ and Vavalà T: Lung cancer and women. Future Oncol 4: 705-716, 2008.

4. Devesa SS, Bray F, Vizcaino AP, et al: International lung cancer trends by histologic type: male:female differences diminishing and adenocarcinoma rates rising. Int J Cancer 117 294-299, 2005.

5. Egleston BL, Meireles SI, Flieder DB, et al: Population-based trends in lung cancer incidence in women. Semin Oncol 36: 506-515, 2009 .

6. Ondrusova M, Muzik J, Hunakova L, et al: Trends in the lung cancer incidence and mortality in the Slovak and Czech Republics in the contexts of an international comparison. Clin Transl Oncol 14: 659-666, 2012.

7. Eilstein D and Eshai K: Lung and breast cancer mortality among women in France: future trends. Cancer Epidemiol 36 e341-e348, 2012

8. Thompson CA, Waldhör T, Schernhammer ES, et al: Smoking and lung cancer: current trends in Austria. Wien Klin Wochenschr 124: 493-499, 2012.

9. Youlden DR, Cramb SM and Baade PD: The international epidemiology of lung cancer: geographical distribution and secular trends. J Thorac Oncol 3: 819-831, 2008.

10. Malvezzi M, Bertuccio P, Levi F, et al: European cancer mortality predictions for the year 2012. Ann Oncol 23: 1044-1052, 2012.

11. Stahel RA: Adenocarcinoma, a molecular perspective. Ann Oncol 18 (Suppl 9): 147-149, 2007.

12. Kadara H, Kabbout M and Wistuba II: Pulmonary adenocarcinoma: a renewed entity in 2011. Respirology 17: 50-65, 2012.

13. Li J, Chen P, Li XQ, et al: Elevated levels of survivin and livin mRNA in bronchial aspirates as markers to support the diagnosis of lung cancer. Int J Cancer 132: 1098-1104, 2013.

14. Hartman ML and Czyz M: Anti-apoptotic proteins on guard of melanoma cell survival. Cancer Lett 331: 24-34, 2013.

15. Ye L, Song X, Li S, et al: Livin- $\alpha$ promotes cell proliferation by regulating G1-S cell cycle transition in prostate cancer. Prostate 71: 42-51, 2012.

16. Guo H, Gao YT, Zhang Q, et al: Expression and clinical significance of livin protein in hepatocellular carcinoma. Dis Markers 35: 489-496, 2013.

17. Bavykin AS, Korotaeva AA, Poyarkov SV, et al: Double siRNAtargeting of cIAP2 and LIVIN results in synergetic sensitization of HCT-116 cells to oxaliplatin treatment. Onco Targets Ther 6: 1333-1340, 2013

18. Xu M, Xia LP, Fan LJ, et al: Livin and caspase-3 expression are negatively correlated in cervical squamous cell cancer. Eur J Gynaecol Onco 134: 152-155, 2013.

19. Li F, Yin X, Luo X, et al: Livin promotes progression of breast cancer through induction of epithelial-mesenchymal transition and activation of AKT signaling. Cell Signal 25: 1413-1422, 2013.

20. Dasgupta A, Alvarado CS, Xu Z, et al: Expression and functional role of inhibitor-of-apoptosis protein livin (BIRC7) in neuroblastoma. Biochem Biophys Res Commun 400: 53-59, 2010.

21. Gazzaniga P, Gradilone A, Giuliani L, et al: Expression and prognostic significance of LIVIN, SURVIVIN and other apoptosis-related genes in the progression of superficial bladder cancer. Ann Oncol 14: 85-90, 2003.
22. Xi RC, Sheng YR, Chen WH, et al: Expression of survivin and livin predicts early recurrence in non-muscle invasive bladder cancer. J Surg Oncol 107: 550-554, 2013.

23. Tanabe H, Yagihashi A, Tsuji N, et al: Expression of survivin mRNA and livin mRNA in non-small-cell lung cancer. Lung Cancer 46: 299-304, 2004.

24. Xiang Y, Yao H, Wang S, et al: Prognostic value of Survivin and Livin in nasopharyngeal carcinoma. Laryngoscope 116: 126-130, 2006.

25. Kempkensteffen C, Hinz S, Christoph F, et al: Expression of the apoptosis inhibitor livin in renal cell carcinomas: correlations with pathology and outcome. Tumor Biol 28: 132-138, 2007.

26. Augello C, Caruso L, Maggioni M, et al: Inhibitors of apoptosis proteins (IAPs) expression and their prognostic significance in hepatocellular carcinoma. BMC Cancer 9: 125, 2009.

27. Xi RC, Biao WS and Gang ZZ: Significant elevation of survivin and livin expression in human colorectal cancer: inverse correlation between expression and overall survival. Onkologie 34: 428-432, 2011.

28. Lazar I, Perlman R, Lotem M, et al: The clinical effect of the inhibitor of apoptosis protein livin in melanoma. Oncology 82: 197-204, 2012.

29. Li X, Fan S, Li L, et al: RNA interference-mediated knockdown of Livin suppresses cell proliferation and invasion and enhances the chemosensitivity to cisplatin in human osteosarcoma cells. Int J Oncol 43: 159-168, 2013.

30. Liang YZ, Fang TY, Xu HG, et al: Expression of CD44v6 and Livin in gastric cancer tissue. Chin Med J (Engl) 125: 3161-3165, 2012.

31. Choi J, Hwang YK, Sung KW, et al: Expression of Livin, an antiapoptotic protein, is an independent favorable prognostic factor in childhood acute lymphoblastic leukemia. Blood 109: 471-477, 2007.

32. Nedelcu T, Kubista B, Koller A, et al: Livin and Bcl-2 expression in high-grade osteosarcoma. J Cancer Res Clin Oncol 134: 237-244, 2008.

33. Yang YL, Lin SR, Chen JS, et al: Expression and prognostic significance of the apoptotic genes BCL2L13, Livin, and CASP8AP2 in childhood acute lymphoblastic leukemia. Leuk Res 34: 18-23, 2010.

34. Liu HB, Kong CZ, Zeng Y, et al: Livin may serve as a marker for prognosis of bladder cancer relapse and a target of bladder cancer treatment. Urol Oncol 27: 277-283, 2009.

35. Wang X, Xu J, Ju S, et al: Livin gene plays a role in drug resistance of colon cancer cells. Clin Biochem 43: 655-660, 2010.

36. Sun JG, Liao RX, Zhang SX, et al: Role of inhibitor of apoptosis protein Livin in radiation resistance in nonsmall cell lung cancer. Cancer Biother Radiopharm 26: 585-592, 2011.

37. Crnković-Mertens I, Muley T, Meister M, et al: The anti-apoptotic livin gene is an important determinant for the apoptotic resistance of non-small cell lung cancer cells. Lung Cancer 54: 135-142, 2006.

38. Chang $\mathrm{H}$ and Schimmer AD: Livin/melanoma inhibitor of apoptosis protein as a potential therapeutic target for the treatment of malignancy. Mol Cancer Ther 6: 24-30, 2007.

39. Crnković-Mertens I, Wagener N, Semzow J, et al: Targeted inhibition of Livin resensitizes renal cancer cells towards apoptosis. Cell Mol Life Sci 64: 1137-1144, 2007.

40. Liu B, Han M, Wen JK, et al: Livin/ML-IAP as a new target for cancer treatment. Cancer Lett 250: 168-176, 2007.

41. Abd-Elrahman I, Hershko K, Neuman T, et al: The inhibitor of apoptosis protein Livin (ML-IAP) plays a dual role in tumorigenicity. Cancer Res 69: 5475-5480, 2009.

42. Yu L and Wang Z: Effects of Livin gene RNA interference on apoptosis of cervical cancer HeLa cells and enhanced sensitivity to cisplatin. J Huazhong Univ Sci Technolog Med Sci 29: 625-630, 2009.

43. Wang TS, Ding QQ, Guo RH, et al: Expression of livin in gastric cancer and induction of apoptosis in SGC-7901 cells by shRNA-mediated silencing of livin gene. Biomed Pharmacother 64: 333-338, 2010.

44. Yang D, Song X, Zhang J, et al: Therapeutic potential of siRNA-mediated combined knockdown of the IAP genes (Livin, XIAP, and Survivin) on human bladder cancer T24 cells. Acta Biochim Biophys Sin (Shanghai) 42: 137-144, 2010.

45. Yang D, Song X, Zhang J, et al: Suppression of livin gene expression by siRNA leads to growth inhibition and apoptosis induction in human bladder cancer T24 cells. Biosci Biotechnol Biochem 74: 1039-1044, 2010. 
46. Liu $\mathrm{H}$, Wang $\mathrm{S}$, Sun $\mathrm{H}$, et al: Inhibition of tumorigenesis and invasion of hepatocellular carcinoma by siRNA-mediated silencing of the livin gene. Mol Med Rep 3: 903-907, 2010.

47. Yuan B, Ran B, Wang S, et al: siRNA directed against Livin inhibits tumor growth and induces apoptosis in human glioma cells. J Neurooncol 107: 81-87, 2012.

48. Chen F, Yang D, Wang S, et al: Livin regulates prostate cancer cell invasion by impacting the NF- $\kappa \mathrm{B}$ signaling pathway and the expression of FN and CXCR4. IUBMB Life 64: 274-283, 2012.

49. Liu X, Wang A, Gao H, et al: Expression and role of the inhibitor of apoptosis protein livin in chemotherapy sensitivity of ovarian carcinoma. Int J Oncol 41: 1021-1028, 2012.

50. Wang XT, Xie YB and Xiao Q: siRNA targeting of Cdx 2 inhibits growth of human gastric cancer MGC-803 cells. World J Gastroenterol 18: 1903-1914, 2012.
51. Ou JM, Ye B, Qiu MK, et al: Knockdown of Livin inhibits growth and invasion of gastric cancer cells through blockade of the MAPK pathway in vitro and in vivo. Int J Oncol 44: 276-284, 2014.

52. Trinh DT, Shibata K, Hirosawa T, et al: Diagnostic utility of CD117, CD133, SALL4, OCT4, TCL1 and glypican-3 in malignant germ cell tumors of the ovary. J Obstet Gynaecol Res 38: 841-848, 2012.

53. Jin T, Branch DR, Zhang X, et al: Examination of POU homeobox gene expression in human breast cancer cells. Int J Cancer 81: 104-112, 1999.

54. He YQ, Zhuang li, Liu SY, et al: Mechanism of the apoptosis induction by Flavopiridol synergizes TRAIL in SPC-A1 cell. Chinese Journal of Cancer Prevention and Treatment 20: 730-733, 2013 (In Chinese) 